
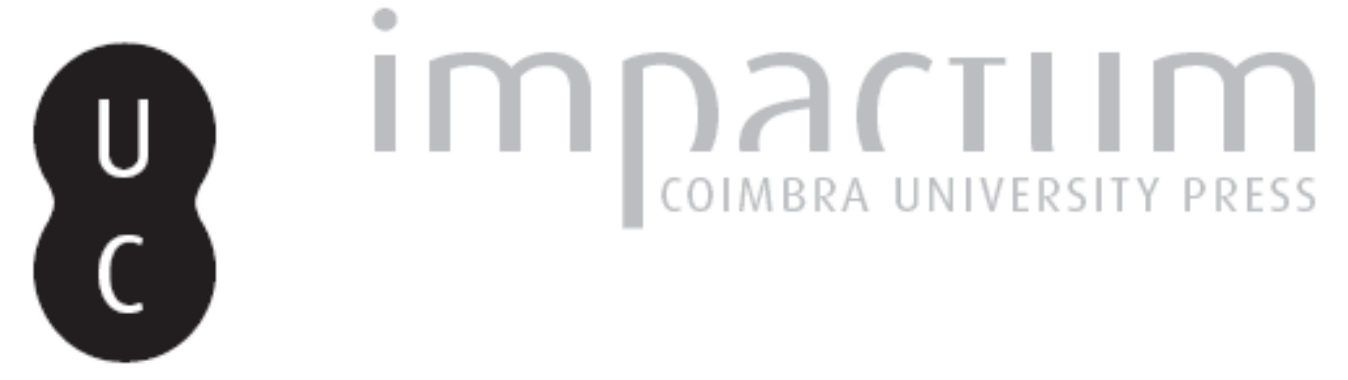

\title{
Just how socratic are Plato's "Socratic" Dialogues?
}

Autor(es): Rowe, Christopher

Publicado por: Imprensa da Universidade de Coimbra

URL persistente:

URl:http://hdl.handle.net/10316.2/42270

DOI:

DOI:https://doi.org/10.14195/2183-4105_2_4

Accessed : $\quad$ 26-Apr-2023 14:12:21

A navegação consulta e descarregamento dos títulos inseridos nas Bibliotecas Digitais UC Digitalis, UC Pombalina e UC Impactum, pressupõem a aceitação plena e sem reservas dos Termos e Condições de Uso destas Bibliotecas Digitais, disponíveis em https://digitalis.uc.pt/pt-pt/termos.

Conforme exposto nos referidos Termos e Condições de Uso, o descarregamento de títulos de acesso restrito requer uma licença válida de autorização devendo o utilizador aceder ao(s) documento(s) a partir de um endereço de IP da instituição detentora da supramencionada licença.

Ao utilizador é apenas permitido o descarregamento para uso pessoal, pelo que o emprego do(s) título(s) descarregado(s) para outro fim, designadamente comercial, carece de autorização do respetivo autor ou editor da obra.

Na medida em que todas as obras da UC Digitalis se encontram protegidas pelo Código do Direito de Autor e Direitos Conexos e demais legislação aplicável, toda a cópia, parcial ou total, deste documento, nos casos em que é legalmente admitida, deverá conter ou fazer-se acompanhar por este aviso.

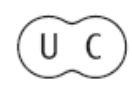




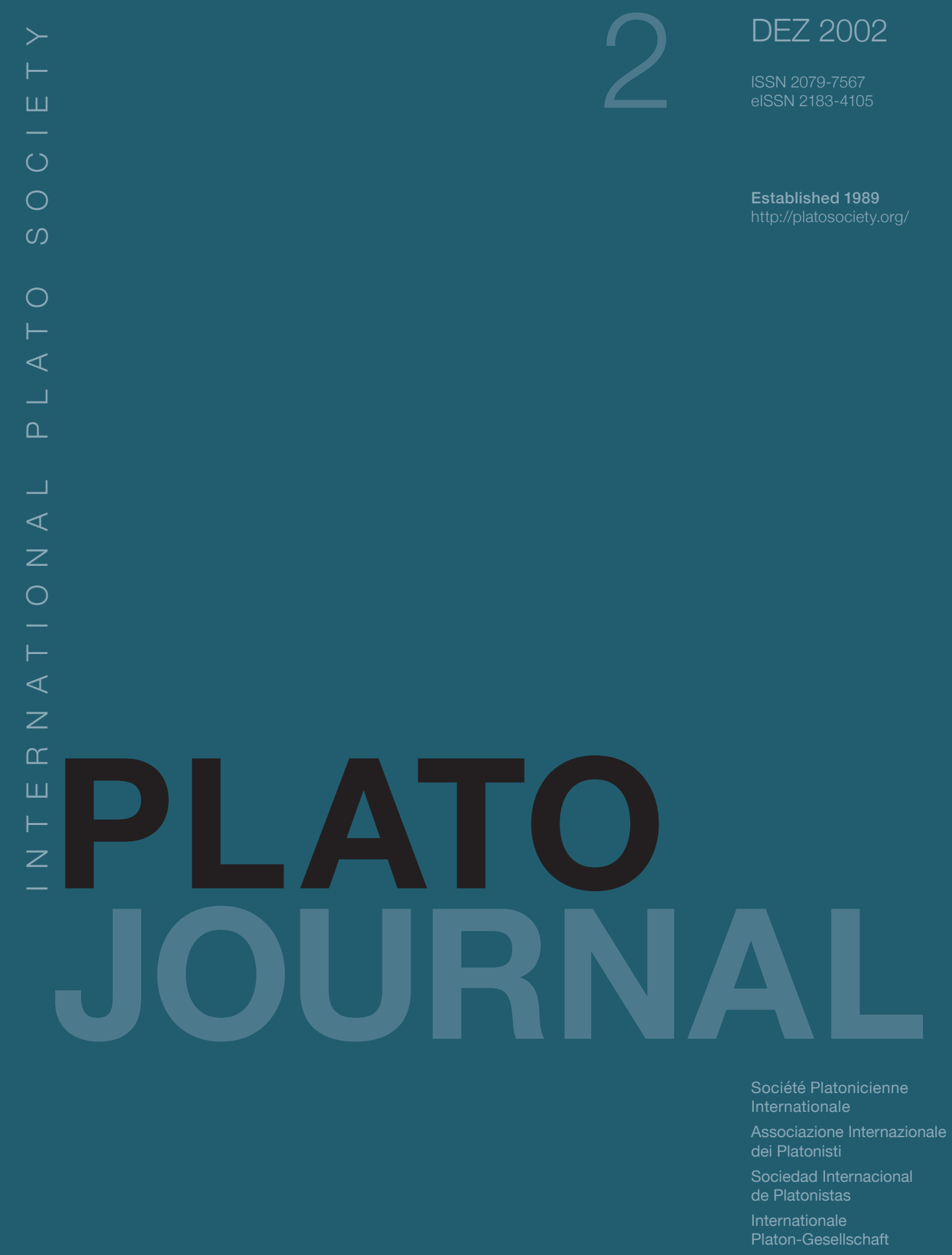




\section{Just How Socratic Are Plato's "Socratic" Dialogues?}

ROWE, Christopher, in 2. Plato 2 (2002),

[En ligne], January 2002

\section{Kahn's Critique of Vlastos's Socrates}

Plato and the Socratic Dialogue is, among other things, a sustained attack on the hypothesis of a 'Socratic' period in Plato. Two main arguments in favour of the hypothesis are usually advanced; the two are closely interrelated.

First, there is the sort of argument that we find developed in Vlastos's book on Socrates.

I have been speaking of $a$ Socrates in Plato. There are two of them. In different segments of Plato's corpus two philosophers bear that name. The individual remains the same. But in different dialogues he pursues philosophies so different that they could not have been depicted as cohabiting the same brain throughout unless it had been the brain of a schizophrenic. They are so diverse in content and method that they contrast as sharply with one another as with any third philosophy you care to mention, beginning with Aristotle's [1] .1

This is, as Vlastos says, a 'large claim', but a (reasonably) clear one: the two philosophies in question are so different that no sane mind could go on for long entertaining both. According to Vlastos and many others, there is a very clear break ('in content and method') between two 'segments' of the Platonic corpus which needs explanation - and one way of explaining it is indeed that they reflect the workings of two different minds. The explanation is all the more tempting because there are, in a sense, already two people there: the author and his character, and we know that the one, and the original of the other, were philosophers.

Of course, as Vlastos himself admits, the internal evidence of the dialogues themselves would also be consistent with Plato's having first developed one of the two philosophies, then the other: 'there is no intrinsic reason why both of these philosophies, despite their polar differences, could not have been Plato's own original creations at different periods of his life' (p. 81). This is where the second main argument for a Socratic phase in Plato comes in: other authors, notably Aristotle and Xenophon, positively identify differences between Socrates' philosophy and Plato's; and these differences happen to show remarkable similarities to the alleged differences between Vlastos's first segment of the Platonic corpus and his second.

The case Vlastos argues, or one very like it, has been very widely accepted; and indeed it looks a powerful case - especially given its apparent coincidence with the results of stylometric studies of Plato. Vlastos is by no means alone in having represented the SocratesPlato split as ('arguably', p. 46) confirmed by such studies: 'Socrates', on his account, is represented by early - or elenctic -

dialogues, 'Plato' by middle (and later) ones, with a group of transitional dialogues in between the two. However as Kahn has shown, with such ease that one wonders how such an idea gained curency in the first place, the stylometrists' three groups of dialogues do not in fact coincide with Vlastos's early, middle, and late, for in their division of the corpus three 'middle' dialogues turn up in the first group along with the early ones. Obviously, these three might have been the last of (the stylometrists') first group; but since there are no clear stylistic criteria available for ordering the members of that first group relative to each other, stylometry ceases to offer any independent support to the hypothesis of a distinctively Socratic phase in Plato.

Kahn, for his part, abandoning talk of 'early' and 'middle', proposes that all the stylometrists' Group I dialogues are meant to be taken together: that is, all the dialogues apart from Republic, Phaedrus, Parmenides, and Theaetetus, constituting Group II, and Sophist, Statesman, Philebus, Timaeus-Critias and Laws, constituting Group III. Kahn's is what might be called a modified, or partially, unitarian view. Dividing the first group into six stages - which represent (perhaps) an ideal reading order, not a chronological development - he suggests that these are meant to 'provide us with various points of entry, various degrees of ingress, into the Platonic thought-world that finds its fullest expression in the Republic' (p.48). The Phaedrus, also in group II, Kahn reads as looking back on Plato's earlier work and forward to the later dialogues, which (he claims) are themselves more different from the earlier in terms of form than in terms of content - but that is beyond the scope of the present discussion, and mainly of Kahn's book too.

One key claim underlying Kahn's interpretation is that we should not expect Plato to tell us, on every occasion, everything that he is 
thinking. On the contrary: in the relevant dialogues (so Kahn claims) he typically holds back on us. We may contrast Vlastos's treatment of Plato in the context of the (so-called) 'Socratic' dialogues:

$[\mathrm{M}] \mathrm{y}$ hypothesis ... proposes ... that Plato in those early works of his, sharing Socrates' basic philosophical convictions, sets out to think through for himself their central affirmations, denials, and reasoned suspensions of belief by pitting them in elenctic encounter against the views voiced by a variety of interlocutors. In doing this Plato is producing, not reproducing, Socratic philosophizing. Employing a literary medium which allows Socrates to speak for himself, Plato makes him say whatever he - Plato - thinks at the time of writing would be the most reasonable thing for Socrates to be saying just then in expounding and defending his own [i.e. Socrates' own] philosophy. (p.50.)

So, on this account, the dialogues in question reveal us Plato actually doing philosophy, and wrestling with (Socrates') problems (in a Socratic kind of way); whereas for Kahn they are above all literary constructions, a means of expounding positions already reached. If anyone were to object that this hardly seems a very efficient method of exposition (so indirect, so complex, just so difficult, sometimes, to interpret at all), then Kahn's 'ingressive' interpretation is already armed to meet that objection: Plato is just holding back, and if we stay with him we shall finally get the point, cumulatively. The same features - the particular indirectness, the complexity, the difficulty of a dialogue such as the Charmides - are perhaps more damaging to Vlastos's view: it is just extraordinarily hard to be sure one is seeing through to Plato's thought-processes. In other words, one is likely to feel strongly that he is up to something in these dialogues, that is, he is not simply doing philosophy with, or on behalf of, Socrates. But it is another matter whether that something is (or includes) what Kahn proposes; and although we, or some of us, may readily agree that there are some clear cases of Plato's (that is, of his Socrates') holding out on us, as for example in aporetic dialogues, it neither follows, nor does Kahn argue that it follows, that this is what Plato typically does.

A further, and more ambitious, claim of Kahn's is that the historical Socrates' own ideas were relatively unformed and unarticulated; and that most of what is of philosophical interest (or literary, or both) in the 'Socratic' dialogues is actually due to Plato. Kahn's 'minimal view' of the historical Socrates (ch.3 sect. 5), based on theApology, even denies him the three things Aristotle explicitly ascribes to him (the definition of virtue as knowledge, the denial of akrasia, and the pursuit of universal definitions). Aristotle and Xenophon - Vlastos's two main witnesses - are dismissed as unreliable, Xenophon getting particularly short shrift. In brief, the building-blocks which interpreters (such as Vlastos) have used to reconstruct a Socrates apud Platonem are to count as 'Socratic' only in the sense that they may be descended from some rather less interesting things that Socrates actually said.

Thirdly, of course, and perhaps most crucially, Kahn claims - as the (moderate) unitarian that he is - that these 'Socratic' elements, if properly understood in their contexts, are in any case capable of being reconciled with the thinking of the 'middle' dialogues. We can presumably dismiss the possibility that the whole of Kahn's Group I and theRepublic is actually Socratic, rather than Platonic; that sort of idea had its day once, but no one would now seriously propose it (who would now claim that the voice of the main part of the Republic is really Socrates'?). In that case, if Kahn can show that the only real break in these dialogues is between the Apology and the rest - or, to put it better, if he can show that the various parts of the rest sit happily together, so as to form an essentially coherent whole, then he is home and dry: we would have no reason to cordon any of it off and call that distinctively 'Socratic'. I shall therefore concentrate my attention in the present paper on this aspect of Plato and the Socratic Dialogue. Kahn says:

I want to deny any fundamental shift in philosophical position between such so-called Socratic dialogues as the Laches, Charmides, and Protagoras, on the one hand, and the Phaedo and Republic on the other hand. There is obviously a great deal of doctrine in the latter works that is absent from the former. But the argument from silence has no grip on an author as cunning as Plato. (p. 40)

So my question is: is there any 'fundamental shift in philosophical position' within the seventeen works (not counting the Phaedrus) that Kahn considers, or not? 'Philosophical position' is, from my perspective but not perhaps from Kahn's, a little too rigid; one might say 'shift in philosophical direction', allowing for the possibility that Plato might sometimes be trying something out, maybe over a considerable period, without having adopted it, quite, as his 'position'. We should not, presumably, rule out the possibility of experimentation and exploration in a philosophical writer - although of course that would already mean adopting a more Vlastos-like, less Kahn-like, story. One crucial question, but one which I shall have no time to discuss, is whether there are actually any parts of the dialogues that are more plausibly taken as experimental, rather than as parts of a sophisticated plan of exposition.

Before I get on to this central issue, however, I should like to say a little about Kahn's treatment of Aristotle's evidence. The presentation of the case against Xenophon's looks fairly impressive; and although it may be done rather too swiftly - especially perhaps, in light of Vivienne Gray's new study of the working methods of theMemorabilia2 [2] - Aristotle is probably more central to the argument, if only because he looks so straightforward and uncomplicated a witness ('Socrates did this, did that; this and that can be attributed to him'), and looks as if he knows what he is talking about.

\section{The Value of Aristotle's Evidence for Socrates}

Kahn's book is timely, for several reasons. The hypothesis of a 'Socratic' period in Plato has largely been responsible for the spawning (or 'greening') of a new area of scholarship, 'Socratic studies' - which usually, and oddly, ignores the other Socrateses that appear in the fourth and third centuries B.C. and later. Kahn himself starts by focussing on other writers of Sôkratikoi logoi, some of 
whom evidently predated Plato; this Socratic literature, he argues, was 'imaginative and essentially fictional' - so why then should we expect Plato's Socratic writing to be any different? If one then adds in the various figures of Socrates created by the various philosophical schools (the minor Socratics, or the Stoics), then the odds seem heavily stacked against the historicity of Plato's account, insofar as his Socrates, or Socrateses, are different.

But this is to leave Aristotle out. Aristotle seems to tell us that Plato's Socrates - either the one in the 'Socratic' dialogues, or some version of him - $i$ s the real thing. The amount that Aristotle tells us is relatively small; but he is always there, if the hypothesis of a Socratic period in Plato is in need of support. Indeed, we could probably not have understood Aristotle's brief remarks without the Socratic dialogues, which serve to give them shape and sense. To this extent 'Socratic studies', understood as an attempt to round out from Plato our picture of the great man as he was is not just shadow-boxing - although every time it moves decisively away from the Aristotelian evidence (maybe with some small help from elsewhere, including Xenophon) it is in danger of becoming, or actually becomes, mere uncontrolled speculation. There would be nothing except wishful thinking to support the view that everything in the 'Socratic' dialogues is genuinely Socratic; indeed there is good reason to doubt whether it is, since at some point Plato leaves Socrates behind, but retains him as a figure with a central speaking part. In any case we have no obviously valid criteria for deciding in the first place which are 'Socratic' dialogues and which are not. This is a difficulty that is recognised by Vlastos's category of 'transitional' dialogues - and also, perhaps, by the shifting and not wholly compatible descriptions, in the literature, of the 'Socratic' dialogues. Are they 'elenctic', as Vlastos has it, or 'aporetic', or - as Kahn himself may suggest, as a non-believer - 'dialogues of definition'? Still, Aristotle does - apparently - give respectability to the general notion of 'Socratic' dialogues, at least to the extent that we may be able to say that some are more Socratic than others.

Not, however, according to Kahn. How good are his grounds? Roughly, they are (i) that Aristotle's record as a historian of philosophy is generally not very good - he typically 'construes his [Presocratic] predecessors as interlocutors in a timeless discussion that leads to the formulation of his own system' (p. 80), and is no better on Plato; (ii) there are signs that his 'reporting' of Socrates similarly presupposes his own ideas; (iii) there are also signs that this 'reporting' is actually either based on, or distorted by, his reading of the dialogues, and perhaps of Xenophon too; and (iv) on one crucial occasion he actually quotes Plato's Socrates as if he were the real thing. Kahn's view seems to be that Aristotle was in possession of some sort of oral account, only not an accurate one: '[i]f there was any oral tradition [sc. on Socrates] in the Academy, we may well doubt that it could contain accurate information on the unrecorded teachings of the master, some thirty or forty years after his death.' He concludes:

that Aristotle ... is [not] in a position to tell us anything about the philosophy of Socrates that he has not learned from Plato's dialogues [except that 'Socrates' philosophy' did not include everything attributed to 'Socrates' there - so much he will have got from the 'oral tradition']. He is unable to [tell us anything more than that] because he arrived on the scene too late; he was separated from Socrates by the dazzling screen of Plato's portrayal. (p. 87)

All this is persuasive, up to a point; it is a way of understanding how Aristotle could have come by what he tells us about Socrates (if it is not true), simultaneously casting doubt on the possibility that he was in a position to know the truth in any case. Yet, if there were a distinctive Socratic position (or 'philosophy', as Vlastos calls it), presumably it would have been all the more likely to have been remembered with reasonable accuracy. Much, then, will depend even here on the final and in a way crucial part of the present discussion - in which I shall, finally, claim that there was, or may have been, such a 'philosophy'. I believe, in fact, that there are grounds for doubt whether, if Aristotle knew properly about the ideas in question, they interested him sufficiently to write them down accurately; he might have got the detail from Plato's texts, but in fact he seems not to have bothered. If so, it would not have been the only occasion on which Aristotle proved himself a less than punctilious and attentive reader of his master (I think here of his treatment of the Republic and Laws in the Politics, and of what he makes of the Lysis in the Nicomachean Ethics). My own view, in fact, is that Aristotle's reports suggest him to have been relying - to a large extent - on a broad tradition about Socrates, rather than on Plato's texts: he has a picture of Socrates as ethical philosopher that is, perhaps, even something of a caricature. He thinks Socrates' position is just bizarre. From this perspective, contra Kahn, Aristotle might have done better to read more of Plato on Socrates rather than less, since then he might have got a clearer notion of what Socrates was really about.

What of Kahn's other points? The first is well-taken: Aristotle is generally a poor historian of philosophy. But, as far as I can see, there is nothing to stop us simply rejecting the other three, insofar as - again - they only tell us how things must/might have happened if Kahn's thesis is correct. To sum up: the case against Aristotle as a witness is quite strong, without being terminally damaging - he just is not a reliable reporter of other people's ideas. So it would be good if the case for a Socrates in Plato did not have to rely too heavily on him. The next section will suggest that - perhaps - the defence has at least some small amount of corroborating evidence.

\section{The Developmental Approach to Plato: Forms}

A second reason for calling Kahn's book 'timely' is its resistance to the 'developmental' approach to Plato. 'Developmentalism' Kahn himself describes it - is, roughly, the kind of approach that typically uses Plato's presumed intellectual development to explain apparent inconcinnities of 'doctrine' within the corpus. At least in the English-speaking world, this approach has become virtually, if not actually, standard - strangely, since we have either little or no independent evidence about Plato's intellectual evolution (if we did, Kahn might not have needed to write his book). The obsession with development essentially belongs to a period before the relatively 
recent explosion ofliterary interest in Plato: as soon as one begins asking questions about Plato's intended readership, or indeed his purpose in writing at all, then the developmental approach immediately begins to look like a golfer with only one club. But still it lingers on - and maybe Kahn's book will help to dispatch it, or at least cut it down to size.

Better 'cut it down to size': some discontinuities in Plato may ultimately need to be put down to changes of mind, and to deny that in principle, and in advance, would be absurd. The objection is only to our beginning from the assumption that Plato's thought (must have) evolved; there are other options to be explored first. So, to use an example that will turn out to be highly relevant, it seems the height of implausibility to suppose that the only explanation of the absence from the Symposium of the conception of an immortal soul [3] - when immortality becomes one of the major themes - is that Plato has either not thought of it yet or has abandoned it. Here, in fact, I agree absolutely with Kahn: the question is all about context, and (more speculatively, but still plausibly) the intended readership.

But there are, nevertheless, at least two major areas where to adopt a unitarian view does continue to seem radically counter-intuitive: one metaphysical, the other to do with the explanation of action. The first, of course has to do with forms. Vlastos puts the issue like this: there is; in some dialogues, a Socrates 'who had a grandiose metaphysical theory of 'separately existing' forms and of a separable soul which learns by 'recollecting' pieces of its pre-natal fund of knowledge'; in others, there is a Socrates who 'has no such theory'. (p. 48)

This difference [Vlastos claims] is so telling that a strong case for my main claim [sc. about the distinctness of what we may call Socrates I from Socrates II in Plato] could have been made just from this even if it had stood alone: when we consult Aristotle's and Xenophon's testimony what we learn from it on just this [subject] would allow us to infer securely that the philosopher who believed in [Socrates II]'s separable transmigrating soul and 'separate' Forms could not have been [Socrates I], the moral teacher in Xenophon's and Plato's Socratic writings who has no truck with metaphysical speculation. (p. 82)

For Kahn too, forms are absolutely central to the whole issue; indeed they are central to Plato's whole project, from the beginning separate forms may not be mentioned explicitly in a large number of his Group I dialogues, but even when they are not there is (he insists) nothing against supposing that they are not there in the background.

Now here I find myself in major disagreement both with Vlastos and with Kahn; it seems to me that both considerably overstate the difference that forms make within the Socratic-Platonic enterprise. In short, 'separate' forms do not constitute a 'grandiose metaphysical theory'; although 'separation' (whatever that entails) involves fundamental philosophical consequences, it is essentially a way of expressing an objectivist, or (if you like) platonist, view of things, which is likely to have been at least implicit in whatever views we finally attribute to Socrates. It follows that I am also unhappy with Kahn's picture of Plato as a 'metaphysical visionary', for whom 'the domain of unseen reality is the place of origin from which the human spirit or the rational psyche has come, and to which it may under favourable circumstances return' (p. 66). This, in my view, is essentially to mistake the medium, or the metaphors, for the message.

\section{Kahn's Critique of 'Socratic' Moral Psychology}

I now pass on to the other area in which I suggested that unitarianism is likely to look counter-intuitive: the treatment of the explanation of action, or of moral psychology, in Kahn's Group I dialogues. Let me begin by outlining Vlastos's and Kahn's interpretations here; I shall then suggest that both Vlastos and Kahn have mis-stated some aspects of the theory or theories involved, before going on to try to suggest some conclusions.

Vlastos essentially makes the following relevant claims about Socrates: (i) he is a moral philosopher; (ii) he is committed to the idea of the sovereignty of (moral) virtue; (iii) for him, reason, or the intellect, is alone responsible for the way we act; (iv) for him, if we go wrong (and act contrary to the virtues), that is solely because of ignorance; and (v) he therefore gives the emotions no role in the explanation of action. The introduction of the tripartite psychology in the Republic clearly makes (iii), (iv), and (v) untenable, because it proposes that the emotions (in the guise of the irrational parts of the soul) are themselves capable of causing actions, independently of reason. Therefore we have another basis - according to Vlastos - for distinguishing a Socrates I and a Socrates II in Plato, and (given Aristotle's and Xenophon's evidence) for identifying a genuine Socrates apud Platonem [4]. Now this is essentially the version of 'Socratic intellectualism' that Kahn seeks to show is not in Vlastos's Group I dialogues (nor indeed in his own Group I). Here is Kahn's own summary of it, which is rather fuller:

[What is known as the intellectualist moral psychology of the 'early' dialogues] consists of two closely related themes: (1) a conception of virtue in terms of knowledge; knowledge is necessary and sufficient for correct action, so anyone who knows what is good will do what is good; and (2) the Socratic paradox that no one does evil voluntarily. These two views are logically connected by (3) the assumption that everyone wants what is good; if anyone does what is bad, that can only be by mistake. Hence virtue consists in a correct recognition of what is good. (p. 225)

Kahn gives particular emphasis to what I have labelled Vlastos's (v):

... we should seriously consider what is entailed by reading these arguments [i.e. various arguments in the target dialogues] as a 
descriptive account of how human beings actually behave. We are immediately struck by the total disregard of emotional, affective, or otherwise non-rational factors in human motivation. The only emotive consideration in the relevant sections of the Gorgias, Meno, and Euthydemus is the desire for happiness or a desire for the good. And if we look closely at the corresponding arguments in the Protagoras, we see that desire is not even mentioned. (p. 227)

Kahn's view is unmistakeable: the theory in question is so obviously false that no sensible person could be supposed to have entertained it. This, Kahn thinks, needs to be taken into account whenever we read the Platonic passages to which Vlastos and others appeal in constructing their intellectualist Socrates; we will then be ready to resort to other explanations of those passages. That my diagnosis of Kahn's strategy is fair is, I think, shown by a passage like the following:

[Socrates in the Protagoras seems to deny 'that other motivating forces can prevail over their better judgment'] To realise just how extraordinary this view is, we need only compare it with other statements of the paradox [sc. that no one does/goes wrong willingly]. The central thought in the passages we have surveyed from other dialogues is this: that a correct judgment concerning what is good and what is bad is the decisive factor in human life, the only guarantee that one will live a good and happy life. Virtue is precisely that form of knowledge or wisdom that provides correct judgment in every case. The paradoxes of the Gorgias and theMeno, which insist that everyone wants what is good and will do what is wrong only by mistake, do not consider (and hence do not exclude) the possibility that someone might act against their better judgment. For example, the first paradox of the Gorgias argues that many people, who do what they think is best, do not do what they want, because their judgment is bad: that is, because they lack knowledge of the good (Gorgias 468C-D). Such paradoxes clearly have a normative-protreptic appeal. They are designed to provoke the interlocutor (and the reader) into reflecting on what it is that is truly good for them. For it appears obvious that people do in fact want bad things - things bad for them and things bad absolutely. In challenging these appearances, the paradoxes do not only serve to emphasize the importance of moral knowledge. According to the interpretation offered [in this book], they also aim to put Callicles and his like in touch with the healthy part of themselves, the part that really wants what Socrates and Plato understand by the good: in the first instance, a virtuous soul. (pp. 230-1)

The starting-point, then, is that we $d o$, patently, act against our better judgment, and want bad things; and Plato knows that. So he cannot mean the paradoxes to describe human nature; so he must be using them for some other purpose - a 'normative-protreptic one'. What will make all the difference in the world is our thinking, and reaching a correct judgment about what it is all for; this is 'the only guarantee that one will live a good and happy life'.

It is not much of a 'guarantee', apparently, because our emotions may always intervene. There may be 'a deep, half-conscious desire for the good [i.e. the real good, what philosophy identifies as the good] in every human soul' (p. 225), but that - so Kahn's reconstruction of Plato's idea goes - has to cohabit with other, irrational, desires, which only an extraordinary figure like Socrates is capable of controlling. This desire for the good, Kahn claims, 'is ultimately identical with rationality as such', a desire

that can [nevertheless] be experienced as eros. If all were able to grasp the nature of the good as Plato conceives it, no one would pursue any other goal. Most of us, however, live in the cave of greed and sensuality, in the pursuit of wealth or honor or power. Only the true philosopher can recognize the goal of everyone's deepest desire, that for the sake of which all other things are dear, and can pursue it with some hope of success. The unity of virtue points to the total transformation that must occur if such a pursuit is to be successful [and would perhaps provide a 'guarantee', in this case?]. (p. 273)

In short, Plato has a fairly ordinary-looking theory of moral psychology - ordinary, that is, in that it takes account of the salient facts of human experience (especially mental conflict, and the role of the emotions), but he overlays that ordinary-looking theory with a 'normative-protreptic' theory of 'real' desire - a desire which lies deep in all of us, but which unfortunately in most of us never rises fully into our consciousness and so remains permanently unfulfilled. This is how we are to understand the statement in the Republic to the effect that the good is 'what every soul pursues, and it is for the sake of this that it does (prattei) everything' - or in Kahn's version, 'performs all its actions' (505D11-E1).

In order to make this passage compatible with the introduction of the tripartite psychology in Book IV of the same dialogue, Kahn then proposes that Plato here restricts the sense of 'action'. On his view, what Plato means in Republic VI is the same as what he always means when he has Socrates talk about desire and the good - for instance atGorgias 468B-C: 'When people act, they do all their actions for the sake of what is good ..., for it is only good things that we want'.

Now this view is not given up in the Republic [sc. as we might have thought, in light of Book IV] but forcefully reasserted [i.e. at 505D11-E1]. So Plato maintains that the desire for good is universal in two respects: everyone has such a desire; and the good is the aim of every voluntary action. Everyone desires good things, because everyone has a rational principle, the logistikon, the capacity to calculate benefit and harm. And in the claim that the soul aims at the good in every action we recognize, in effect, the Socratic paradox. According to this paradox, failure to aim at the good will make the action involuntary, and hence not a proper act. (pp. 273 4)

One could, I think, raise serious objections to this move (after all, it leaves us with a somewhat odd conception of the voluntary, and of what constitutes an action). Nevertheless, it is clear that some very hard thinking is needed in order to explain how the Book VI passage can sit alongside tripartition. What is important for present purposes is just that they do sit alongside one another. If Kahn 
can make good his claim that what Republic VI is saying is what the Gorgias is saying, then he will have gone a long way towards establishing his case. If the Republic itself contains both what is supposed to be a distinctively 'Socratic' idea and its alleged Platonic rival, the basis for distinguishing between them will indeed begin to look decidedly weak.

\section{A Restatement of Socratic Moral Psychology}

There seems, however, to be a considerable difference between 'it is for the sake of [the good] that [every soul] performs all its actions' (Republic) and 'it is only good things we want' (Gorgias) - or 'there is nothing else that human beings desire (erôsin) except the good' (Diotima in the Symposium 205e7-206a1). The first is a claim about action, while the second is a claim about desire; since the Republic makes a different claim about desire, namely that not all desire is for the good, prima facie there is still a contrast between (what are for Kahn) pre-Republic dialogues and the Republic itself. Kahn says that

[W] will misconstrue the theory of the Symposium and the arguments of the Gorgias and Meno if we imagine that in claiming that no one desires bad things but that all action aims at the good, Plato (or Socrates) is attempting to offer a general account of human motivation, which he implausibly reduces to a judgment concerning what is good. As we have seen [in ch. 8], only the cunning argument of Protagoras 351ff. makes such general claims, for its own very special purposes [i.e. as 'the decisive move in an elaborate dialectical "revision" of the notion of courage', designed for Protagoras]. In dialogues before the Republic, Plato offers no general account of moral psychology. On the contrary, his discussion of desire is systematically limited to rational desire for the good, since that is the fundamental thought underlying the Socratic paradox. (pp. 263-4)

The main justification for these claims is, again, what is claimed to be obviously true: since we do in fact desire/want bad things, Plato/Socrates cannot mean what he says - he is playing on the opaque/de dictu and transparent/de re construals of desire (Kahn $\mathrm{p}$. 244, nn. 40-1). But why, apart from the overall requirements of Kahn's interpretation, should we not rather suppose that Socrates/Plato is proposing to redefine the notion of desire - in the way that Kahn has Plato redefining the notion of action? In other words, granted that we all say we at least sometimes want bad things, why should Plato/Socrates not be proposing a theory of desire according to which we are mistaken if we say, or think, that; that it is only ignorance that makes us say or think it; and that all human desire actually is for the good? It is not hard to see how a very basic version of such a theory might work: it would be no different in principle from the case where someone wants desperately to succeed, but always chooses the wrong way of going about it. It seems perfectly plausible in this case to say that it is perfectly obvious what this person wants - i.e. none of the things he actually does. Nor would a general theory along these lines look obviously implausible; we should perhaps need some careful distinctions between desires and impulses, wants and physical needs, and so on, but I see no immediate reason to suppose that this couldn't be fixed. And after all, what Kahn and Vlastos think we can take for granted is itself a theory; it is not as if ordinary models of mental conflict and of human motivation were themselves transparent and unproblematical.

I asked 'why not?'. The obvious answer is still 'because it wouldn't work'. I beg to differ. But there is one point on which Vlastos and Kahn may seem to have the whip hand. What use is a theory of action that leaves no space for the emotions? This was one of the defining features of Vlastos's Socrates; and Kahn talked about 'the total disregard of emotional, affective, or otherwise non-rational factors in human motivation' apparently involved in the intellectualist model. In the last of the longer passages I quoted from the book, he even claimed that the intellectualist model 'implausibly reduces [human motivation] to a judgment concerning what is good'. But that is surely a misunderstanding: on any account of ('socratic', or Socratic) intellectualism, human motivation surely must also involve desire - a basic, universal, unthinking desire for the good. I see no reason why this is not 'emotional', or 'affective'; it is certainly 'non-rational', in the sense that it is, as it were, pre-rational. Kahn in fact accepts that it is an 'emotive consideration', immediately after the sentence alleging 'total disregard of emotional, affective, or otherwise non-rational factors in human motivation'. But he appears to dismiss it: it is '[t]he only emotive consideration', and by the later passage ('implausibly reduces [human motivation] to a judgment concerning what is good') it has apparently dropped out of account entirely. I do not understand this move, especially given that Kahn's own interpretation allows for an intellectual version of just such a universal idea 'a deep, half-conscious desire for the good in every human soul'.

Neither, of course, will 'intellectualism' involve (or perhaps I ought to say: 'Nor ought intellectualism to involve) denying the existence of any number of ordinary emotions, affections, impulses or whatever - on condition that these should not be supposed to cause actions by themselves. But again, I fail to see why we should be so addicted to the idea that it is our emotions, or as Plato puts it, our irrational desires that 'make' us go off the rails. There are certainly many situations in which we think of ourselves as 'giving in' to this or that emotion (Plato's 'beast' within us). Yet I can also see how at least many of the same situations could be redescribed with reference to a judgment, however messily reached, and however badly articulated (if at all), about what was best. That is not, however, a case that I should want to try to make here. Once more, I wish only to prevent intellectualism being pushed off the stage without a hearing - most immediately because Kahn's case partly depends on the assumption that it does not deserve one.

Whether or not intellectualism (in some form) is actually present in the early dialogues (by anyone's definition of 'early') is of course a separate question. I have already indicated the way in which I should want to answer the question, namely positively. But, since I cannot here go into particular passages in the necessary detail, I shall limit myself to suggesting only that there is at least as much reason for supposing Plato in the relevant dialogues to have been interested in, and to be discussing, some form of intellectualism, as 
there is for supposing that he was not and is not. And it is here that Aristotle's evidence again comes back into the picture. Perhaps I may be allowed to go a step further: I still think that the intellectualist interpretation explains more of the phenomena, that is, phenomena in the various relevant Platonic texts, than Kahn's. But what I mean by 'intellectualism' is not what Kahn means by it, or Vlastos means by it. Would this make the 'Socratic' dialogues (roughly, the ones people generally call early) Socratic? There would be a theory there that Plato at some point decisively rejected, the rejection being marked by Republic Book IV; and it would be a theory which is closely bound up with, and would explain, some of the things we are told - fairly reliably - that Socrates thought. We are scarcely in a position to decide whether Socrates worked it out to the degree that Plato did; on the other hand I find it quite plausible to suppose that some of what we do find in aporetic dialogues - or indeed in theProtagoras - is to some degree experimental, and designed to provoke thought, rather than something final. If this is the case, then Socrates' claims to ownership might be diminished. Yet even if Plato did most of the work, Socrates started it - and Plato later went off in another direction; so here are two reasons for calling whatever theory it is (and maybe dialogues associated with it, though things here get more complicated) 'Socratic'. Or perhaps there are three reasons: if Plato was at some stage seriously interested in such a theory, then there really are two radically different philosophies present in Plato. Whether we think of the Socratic one as a failed theory, like Vlastos (or Kahn), or whether we have higher hopes for it, it is quite distinctive, and one might well wonder for how long it could 'cohabit' the same mind that also gave a home to its replacement.

One final point. I said 'what I mean by "intellectualism" is not what Kahn means by it, or Vlastos means by it'. Here is one more respect in which I would differ from their account: for both, if there is any such theory, it has a strong moral colouring. For Vlastos, after all, Socrates is a moral philosopher. But Kahn too assumes that the knowledge Socrates is, or would be, interested in is moral knowledge; and, following Santas, he talks about a 'moral' as well as a 'prudential' version of the Socratic paradoxes - while also claiming that ' $[\mathrm{i}] \mathrm{n}$ the end, and in the larger view, the prudential reading will always collapse into the moral view'. If the prudential version is sometimes presented as 'autonomous', as in the Protagoras, that is 'part of the cunning of [such] dialogues'. If we are taken in, we may be encouraged, as some interpreters have been encouraged, 'to characterize Socrates, or even Plato, as an ethical egoist' (p. 248). I suppose I just have to come clean and say that I am one of these interpreters - and one who thinks to say that 'the prudential reading will always collapse into the moral view' gets it the wrong way round, for both Socrates and Plato. However, since most interpreters, on both sides of the fence, regard both figures as moral philosophers, and the sort of view I propose would raise questions about whether either of them was, this is properly no more than a side issue in the present discussion.

\section{CHRISTOPHER ROWE}

University of Durham.

U.K.

bibiographie

KaHn, C.H., Plato and the Socratic Dialogue: The Philosophical Use of Literary Form, Cambridge, 1996.

GRAY, V.J. The Framing of Socrates. The Literary Interpretation of Xenophon's Memorabilia, Hermes Einzelschriften, 79, Stuttgart, 1998.

Vlastos, G., Socrates: Ironist and Moral Philosopher, Cambridge, 1991.

Footnotes

[1] Gregory Vlastos, Socrates: Ironist and Moral Philosopher, Cambridge 1991, 46.

[2] Vivienne J. Gray, The Framing of Socrates. The Literary Interpretation of Xenophon's Memorabilia (Hermes Einzelschriften, 79), Stuttgart 1998.

[3] It is, at least, not mentioned explicitly ('Diotima is careful never to mention either reincarnation or any conception of immortality that might be laughed to scorn by the urbane company at Agathon's dinner-party', Kahn, 68-9); we need not argue about whether or not it is hinted at in Symposium 208 b4 and 212a7 (Kahn, 345 n. 20).

[4] . This summary is based mainly on Vlastos's Socrates; it is essentially Thesis IV - '[Socrates I] knows nothing of [the complex, tripartite model of the soul], which would have unsettled his conception of moral virtue and undercut his doctrine of the impossibility of incontinence (akrasia)' (p. 48). 